University of Nebraska - Lincoln

DigitalCommons@University of Nebraska - Lincoln

Agronomy \& Horticulture -- Faculty Publications

Agronomy and Horticulture Department

1991

\title{
Inheritance of acid-soil tolerance in sorghum (Sorghum bicolor) grown on an Ultisol
}

C. I. Flores

Mississippi State University

L. M. Gourley

Mississippi State University

Jeffrey F. Pedersen

University of Nebraska-Lincoln, jpedersen1@unl.edu

R. B. Clark

University of Nebraska-Lincoln

Follow this and additional works at: https://digitalcommons.unl.edu/agronomyfacpub

Part of the Agricultural Science Commons, Agriculture Commons, Agronomy and Crop Sciences Commons, Botany Commons, Horticulture Commons, Other Plant Sciences Commons, and the Plant Biology Commons

Flores, C. I.; Gourley, L. M.; Pedersen, Jeffrey F.; and Clark, R. B., "Inheritance of acid-soil tolerance in sorghum (Sorghum bicolor) grown on an Ultisol" (1991). Agronomy \& Horticulture -- Faculty Publications. 944.

https://digitalcommons.unl.edu/agronomyfacpub/944

This Article is brought to you for free and open access by the Agronomy and Horticulture Department at DigitalCommons@University of Nebraska - Lincoln. It has been accepted for inclusion in Agronomy \& Horticulture -Faculty Publications by an authorized administrator of DigitalCommons@University of Nebraska - Lincoln. 


\title{
Inheritance of acid-soil tolerance in sorghum (Sorghum bicolor) grown on an Ultisol
}

\author{
C.I. FLORES ${ }^{1}$, L.M. GOURLEY ${ }^{1}$, J.F. PEDERSEN ${ }^{2}$ and R.B. CLARK ${ }^{2}$ \\ ${ }^{1}$ Department of Agronomy, Mississippi State University, Mississippi State, MS 39762, USA and ${ }^{2} U . S$. \\ Department of Agriculture, Agricultural Research Service, Department of Agronomy, University of \\ Nebraska, Lincoln, NE 68583-0817, USA
}

Key words: agronomic traits, Al-toxicity tolerance, number of roots, tropical acid soil

\begin{abstract}
Inheritance of acid-soil tolerance (generally considered Al-toxicity tolerance) in sorghum [Sorghum bicolor (L.) Moench] is not clear. Forty $\mathrm{F}_{1}$ sorghum hybrids and their 14 parents were grown two seasons in the field at relatively high (67 and $71 \%$ ) and low (43 and $42 \%$ ) Al saturations on an acid Ultisol in Colombia, South America to evaluate the effects of acid soil on agronomic component traits and to better understand inheritance of acid-soil tolerance of sorghum. For plants grown at the high $\mathrm{Al}$ saturation levels, hybrids from acid-soil tolerant $[\mathrm{AS}-\mathrm{T}] \times$ acid soil-sensitive $[\mathrm{AS}-\mathrm{S}]$ crosses were as tolerant as hybrids from AS-T $\times$ AS-T crosses which were as tolerant as their AS-T parents. Hybrids from AS-S $\times$ AS-S crosses were all sensitive to the acid-soil stress conditions. General combining ability (GCA) and specific combining ability (SCA) effects were significant for acid-soil tolerance, and GCA effects were more important than SCA effects. Significant GCA and SCA effects were detected for grain yield and number of roots at the low Al saturation level. Additive genetic effects in these genotypes were important for acid-soil tolerance rating, grain yield, and number of roots at the high $\mathrm{Al}$ saturation level.
\end{abstract}

\section{Introduction}

Extensive genetic variability has been reported for tolerance to acid-soil stress conditions (considered to be primarily $\mathrm{Al}$ toxicity) and other mineral toxicities/deficiencies associated with sorghum [Sorghum bicolor (L.) Moench] grown on acid soils (Bastos, 1982; Boye-Goni and Marcarian, 1985; Duncan 1981, 1983; Duncan et al., 1983a, b; Flores and Gourley, 1987; Flores et al., 1986; Furlani and Clark, 1981; Furlani et al., 1983; Gourley, 1987). However, relatively little information is available on the inheritance of $\mathrm{Al}$ tolerance in sorghum. Genetic information is needed for plant breeders to effectively improve sorghum germplasm for adaptation to acid soils. Several inheritance studies on sorghum tolerance to $\mathrm{Al}$ have been conducted in nutrient solutions
(Bastos, 1982; Boye-Goni and Marcarian, 1985; Furlani and Bastos, 1986; Furlani et al., 1983). However, results from plants grown in nutrient solutions must be validated in field experiments since most acid soils are deficient in various nutrients as well as having toxic levels of elements like $\mathrm{Al}$ and $\mathrm{Mn}$ (Sanchez and Salinas, 1981).

Plant responses to toxic levels of $\mathrm{Al}$ are genetically controlled (Devine, 1982; Duvick et al., 1981; Rhue, 1979). Aluminum tolerance in wheat (Triticum aestivum L.) and barley (Hordeum vulgare L.) grown in nutrient solutions was controlled by one or more dominant genes (Reid, 1969; Rhue, 1979). Aluminum tolerance in maize (Zea mays L.) was reported to be controlled by dominant genes with multiple alleles (Rhue, 1979). Additive gene effects contri- 
buted most to the genetic variation of maize grown in nutrient solutions (Magnavaca et al., 1987). In this latter study, dominance effects accounted for only half as much variation as did additive effects.

Pitta et al. (1979) suggested that a small number of genes with dominant effects controlled acid-soil tolerance in sorghum. This concept was based on the evaluation of hybrid progenies and their parents grown on an acid soil in the field. Aluminum tolerance in sorghum hybrids grown in nutrient solution expressed dominance, and no maternal or cytoplasmic effects were detected (Fulani et al., 1983). Recent studies on $\mathrm{F}_{1}, \mathrm{~F}_{2}$, and $\mathrm{F}_{3}$ populations from crosses involving $\mathrm{Al}$ tolerant (SC283) and Al sensitive (TX415) sorghum parents grown in nutrient solution indicated that $\mathrm{Al}$ tolerance was dominant and controlled by a single gene pair (Furlani and Bastos, 1986). These authors also found that minor genes and genetic modifiers interacted with the major gene pair in the expression of $\mathrm{Al}$ tolerance. Bastos (1982) evaluated $F_{2}$ and $F_{3}$ sorghum populations from $\mathrm{Al}$-tolerant $\times \mathrm{Al}$-tolerant and Al-tolerant $\times$ Al-sensitive crosses, and concluded that the inheritance of $\mathrm{Al}$ tolerance in sorghum was complex and that three or more genes were involved. Furlani (1981) reported that inheritance of aluminum tolerance in sorghum was complex, and the type of genetic mechanism controlling $\mathrm{Al}$ tolerance depended on the germplasm used. Variation in $\mathrm{Al}$ tolerance of sorghum hybrids from different crosses involving Al-tolerant and $\mathrm{Al}$-sensitive parents has also been noted (Borgnovi et al., 1987). Similar observations of acid-soil tolerance were noted for field-grown sorghum (Gourley, 1987).

The objectives of this study were to determine inheritance of acid-soil tolerance in sorghum, and to evaluate the effects of acid soil on several hybrids and their parents.

\section{Materials and methods}

Ten restorer lines and four male sterile lines (Table 1) were crossed to make 40 hybrids, and each of the parents and hybrids were grown two seasons (Season $\mathrm{A}=$ February to June 1986 and Season B $=$ September 1986 to January 1987) on an acid Ultisol (clayey, oxidic, isohyperthermic, Typic Palehumult) at Quilichao, Colombia, South America. Both the hybrids and parents were grown at high (67\% for Season $A$ and $71 \%$ for Season B) and low (43\% for Season A and $42 \%$ for Season B) Al saturation levels, and evaluated for agronomic component and acidsoil tolerance traits.

The chemical properties of the soil are given in Table 2. Nitrogen was applied in a band 30 days after planting at $100 \mathrm{~kg} \mathrm{~N} \mathrm{ha}^{-1}$ as urea. Weeds were controlled with atrazine (2-chloro-4ethylamine-6-isopropylamine-s-triazine) at $1.0 \mathrm{~kg}$ a.i. ha ${ }^{-1}$. Hand hoeing was used as needed to control additional weeds during the study.

The sorghum lines were grown in a randomized complete block design with three replications. Parents were randomized separately from hybrids to avoid possible competition effects resulting from differences in height of parents and hybrids. Plots consisted of 2 rows, $3 \mathrm{~m}$ long, with $0.60 \mathrm{~m}$ between rows. The experimental unit was two $2 \mathrm{~m}$ row segments with uniform plant density in each plot. Plots were over planted and thinned to $9 \mathrm{~cm}$ between plants $\left(200,000\right.$ plants $\left.\mathrm{ha}^{-1}\right)$.

The number of days to flowering ( $50 \%$ bloom) was determined for each entry during the growth

Table 1. Sorghum parental genotypes and their acid soil reactions when grown during Seasons A and B on an Ultisol at Quilicaho, Colombia

\begin{tabular}{llll}
\hline Season A & $\begin{array}{l}\text { Acid soil } \\
\text { reaction }^{\mathrm{a}}\end{array}$ & Season B & $\begin{array}{c}\text { Acid soil } \\
\text { reaction }^{\mathrm{a}}\end{array}$ \\
\hline Male & $\mathrm{T}$ & IS 9945 & $\mathrm{~T}$ \\
IS 7151 & $\mathrm{T}$ & IS 7100 & $\mathrm{T}$ \\
IS 8933 & $\mathrm{T}$ & IS 9636 & $\mathrm{~T}$ \\
IS 3522 & $\mathrm{T}$ & IS 9938 & $\mathrm{T}$ \\
IS 8577 & $\mathrm{T}$ & IS 9826 & $\mathrm{T}$ \\
IS 8931 & $\mathrm{T}$ & M-35585 & $\mathrm{T}$ \\
3DX57/1/1/910 & $\mathrm{T}$ & 3DX57/1/1/910 & $\mathrm{T}$ \\
IS 2765 & $\mathrm{T}$ & PPQ-2 & $\mathrm{T}$ \\
IS 9636 & $\mathrm{I}$ & SC 326-6 & $\mathrm{I}$ \\
SC 326-6 & $\mathrm{S}$ & TX 430 & $\mathrm{S}$ \\
TX 430 & & & \\
& & & \\
Female & $\mathrm{T}$ & IS 1309C & $\mathrm{T}$ \\
IS 7173C & $\mathrm{T}$ & B-Yellow PI & $\mathrm{S}$ \\
IS 12685C & $\mathrm{S}$ & Wheatland Der & $\mathrm{S}$ \\
Wheatland Der & $\mathrm{S}$ & TX 623 & $\mathrm{S}$ \\
TX 623 & &
\end{tabular}

${ }^{a}$ T-Tolerant, I-Intermediate, S-Sensitive. 
Table 2. Chemical properties of acid Ultisol in Colombia, South America for the growth of sorghum hybrids and parents in the A and $B$ season of 1986

\begin{tabular}{|c|c|c|c|c|c|}
\hline \multirow[t]{3}{*}{ Property/Element } & \multirow[t]{3}{*}{ Unit } & \multicolumn{2}{|c|}{ Season $\mathrm{A}$} & \multicolumn{2}{|c|}{ Season B } \\
\hline & & \multicolumn{2}{|c|}{ Al stress } & \multicolumn{2}{|c|}{ Al stress } \\
\hline & & High & Low & High & Low \\
\hline Al saturation* & $\%$ & 71 & 42 & 66.8 & 43.4 \\
\hline Organic matter & $\%$ & 6.5 & 6.5 & 5.6 & 5.7 \\
\hline $\mathrm{pH}$ (1 soil: 1 water $)$ & - & 4.3 & 4.7 & 4.3 & 4.4 \\
\hline \multicolumn{6}{|c|}{ Exchangeable elements } \\
\hline $\mathrm{Al}$ & $\operatorname{cmol}(+) \mathrm{kg}^{-1}$ & 4.00 & 2.45 & 3.50 & 2.50 \\
\hline $\mathrm{Ca}$ & $\operatorname{cmol}(+) \mathrm{kg}^{-1}$ & 1.11 & 2.97 & 1.25 & 2.78 \\
\hline $\mathrm{Mg}$ & $\operatorname{cmol}(+) \mathrm{kg}^{-1}$ & 0.34 & 0.28 & 0.34 & 0.33 \\
\hline $\mathrm{K}^{\circ}$ & $\operatorname{cmol}(+) \mathrm{kg}^{-1}$ & 0.16 & 0.21 & 0.15 & 0.15 \\
\hline $\mathbf{P}$ & $\mu \mathrm{gg}^{-1}$ & 5.4 & 14.0 & 6.6 & 9.8 \\
\hline $\mathrm{Mn}$ & $\mu \mathrm{gg}^{-1}$ & - & - & 78 & 89 \\
\hline $\mathrm{Fe}$ & $\mu \mathrm{g} \mathrm{g}^{-1}$ & 26 & 20 & 13 & 10 \\
\hline $\mathrm{Zn}$ & $\mu \mathrm{gg}^{-1}$ & 2.1 & 1.8 & 1.7 & 2.1 \\
\hline
\end{tabular}

$*$ Percent Al saturation $=\frac{\left.\mathrm{Al} \mathrm{cmol}(+) \mathrm{kg}^{-1}\right)}{\left(\mathrm{Al}+\mathrm{Ca}+\mathrm{Mg}+\mathrm{K} \mathrm{cmol}(+) \mathrm{kg}^{-1}\right)} \times 100$

Soil extracting solutions were $1 N \mathrm{KCl}$ for $\mathrm{Al}, \mathrm{Ca}$, and $\mathrm{Mg} ; 1 N \mathrm{NH}_{4} \mathrm{OAc}$ for $\mathrm{K}$; Bray II for P; and $0.005 M$ DTPA (diethylene triaminepentaacetic acid) for $\mathrm{Mn}, \mathrm{Fe}$, and $\mathrm{Zn}$.

periods. Prior to harvest, plant height and visual acid-soil tolerance ratings [ $1=$ normal green color, vigorous appearance, uniform height and maturity, and well-filled panicles; $2=$ some yellowing of leaves and drying of leaf tips, small panicles, and less vigorous and developed plants; $3=$ severe yellowing and interveinal streaking of leaves, severe drying of leaves, very small panicles and stunted thin plants; and $4=$ severely stunted plants, no panicles or dead plants] were made for each entry. Three random plants within each experimental plot were pulled and the soil removed from the roots. Plants were taken to the laboratory for counting number of main and secondary roots. The soil was sufficiently loose in the field to allow easy pulling of plants with no mechanical digging required. The mean of three root counts from each plot was used in the statistical analyses. All panicles from each harvested plot were combined, air dried for a minimum of seven days, threshed, and grain yields determined. Grain yields were calculated at $14 \%$ seed moisture.

Analyses of variance and genetic analyses followed the procedures described by Ross et al. (1983). Seasons were analyzed individually, as were data from the high and low $\mathrm{Al}$ saturation levels, since error variances were heterogeneous.
Data from parents were not included in analyses used to estimate combining ability. As pointed out by Ross et al. (1983), statistical treatment of fixed lines to draw inferences about hypothetical populations may not be entirely appropriate. With qualifications, quantitative genetic information can be drawn from such studies that may aid in the improvement of acid-soil tolerance in sorghum.

\section{Results and discussion}

The 40 hybrids tested in each season were divided into three types according to acid soil responses of their parents: acid-soil tolerant [AS-T] $\times$ AS-T, AS-T $\times$ acid-soil sensitive [AS-S], and AS-S $\times$ AS-S hybrids (Tables 3 and 4). The AS-T $\times$ AS-T and AS-T $\times$ AS-S hybrid yields at the high Al saturation levels were statistically similar to yields of their AS-T male parents. Yields of AS-S $\times$ AS-S hybrids were low and similar to those of their AS-S parents. When hybrids were grown at the low $\mathrm{Al}$ saturation levels, yield differences among types of hybrids were small. The highest yields were obtained from the AS-T $\times$ AS-T hybrids and the lowest from AS-S $\times$ AS-S hybrids in both 
seasons. Yield increases of the AS-T $\times$ AS-T and AS-T $\times$ AS-S hybrids in season $B$ were lower than those noted in season $\mathrm{A}$.

Hybrids from AS-T $\times$ AS-S crosses grown at the high Al saturation levels of both seasons had similar acid-soil tolerance ratings as hybrids from AS-T $\times$ AS-T crosses (Tables 3 and 4). Hybrids from AS-S $\times$ AS-S crosses grown at the high $\mathrm{Al}$ saturation levels were as sensitive to the acid soil as their parents in both seasons. No differences in acid-soil tolerance ratings were obtained when hybrids and parents were grown at the low $\mathrm{Al}$ saturation levels.

Number of roots for the AS-T $\times$ AS-T and AS-T $\times$ AS-S hybrids and AS-T parents were similar, and higher than those for the AS$\mathrm{S} \times \mathrm{AS}-\mathrm{S}$ hybrids and AS-S parents (Tables 3 and 4). Few thin roots devoid of fine branches were noted for the AS-S $\times$ AS-S hybrids and AS-S parents.

Number of roots for all types of hybrids and their parents were similar when plants were grown at the low $\mathrm{Al}$ saturation levels during both growing seasons (Tables 3 and 4). However, the AS-S parents and AS-S $\times$ AS-S hybrids had significantly lower number of roots than the AS$\mathrm{T}$ parents and AS-T $\times$ AS-T hybrids, respectively, when grown at the high compared to the low Al saturation levels. Number of roots and acid-soil tolerance ratings were positively correlated $(r=0.51)$. Reductions in root growth and number of roots are primary effects of acid soil problems for sorghum grown on an Ultisol (Flores et al., 1988).

Differences in days to flower were markedly different between AS-T and AS-S parents (Tables 3 and 4), but no pattern was detected for differences in days to flower among the types of hybrids. This was probably because of interactions of different maturity genes in the parental lines. However, the flowering date of parents and hybrids appeared to be delayed when plants were grown at the high compared to the low levels of $\mathrm{Al}$ saturation. Delay in flowering and retardation of plant growth and development are typical problems for AS-S sorghum grown on acid soil (Flores et al., 1988).

Plant height of the AS-S $\times$ AS-S hybrids was significantly shorter than that for the AS$\mathrm{T} \times \mathrm{AS}-\mathrm{T}$ and $\mathrm{AS}-\mathrm{T} \times \mathrm{AS}-\mathrm{S}$ hybrids grown at the high $\mathrm{Al}$ saturation level during both seasons (Tables 3 and 4). The differences in plant height among groups of hybrids were likely due to the interaction of genes controlling plant height in sorghum and due to the effect of the high $\mathrm{Al}$ saturation level. Although statistical comparisons were not made, AS-S hybrids and parents were generally shorter than were AS-T hybrids and parents at the high compared to the low $\mathrm{Al}$ saturation levels. Stunting is a common symptom of plant sensitivity to acid-soil stress conditions.

Differences among male and female lines, an indicator of general combining ability (GCA), in the hybrid group were significant for all traits at the high $\mathrm{Al}$ saturation level for both seasons (Table 5). The male $\times$ female interactions, an indicator of specific combining ability (SCA), were also significant for all agronomic component traits except grain yield in season A. Parents were significantly different from hybrids for all traits except grain yield in season A. At the high $\mathrm{Al}$ saturation levels in both seasons, variations due to GCA were generally larger than those due to SCA, implying major importance of additive gene effects for these traits.

When hybrids were grown at the low Al saturation levels, differences in GCA among males and females were also significant for all agronomic component traits except acid-soil tolerance ratings (Table 6). Male-female interactions were significant for all traits except grain yield, acid-soil tolerance ratings, and number of roots in season $\mathrm{A}$ and acid-soil tolerance ratings and plant height in season B. Parents differed significantly from hybrids for all traits except number of roots and acid-soil tolerance ratings in season B. Differences among hybrids and parents for acid-soil tolerance ratings at the low Al saturation levels were not detected. Apparently the stress on plants was not severe enough to show genetic differences among these genotypes.

Agronomic trait data for each hybrid cross and their respective parents are shown in Tables 7-10. Only season B data have been given since trends for both growing seasons were similar. Parents with high GCA or specific combinations of parents for grain yield and acid-soil tolerance can be selected, and may be of immediate usefulness to soghum breeders using high Al saturation stress conditions. Grain yield, acid-soil toler- 
Table 3. Performance of $F_{1}$ hybrids from acid-soil tolerant (AS-T) $\times$ AS-T, AS-T $\times$ acid-soil sensitive (AS-S), and AS-S $\times$ AS-S crosses, female and male parents grown at $71 \%(71-\mathrm{Al})$ and $42 \%(42-\mathrm{Al}) \mathrm{Al}$ saturation at Quilichao, Colombia during season $\mathrm{A}$

\begin{tabular}{|c|c|c|c|c|c|c|c|c|c|c|}
\hline \multirow[t]{3}{*}{ Genotype } & \multicolumn{2}{|c|}{ Grain yield } & \multicolumn{2}{|c|}{ Acid-soil tolerance ${ }^{c}$} & \multicolumn{2}{|c|}{ Number of roots } & \multicolumn{2}{|c|}{ Flowering } & \multicolumn{2}{|c|}{ Plant height } \\
\hline & 71-Al & $42-\mathrm{Al}$ & 71-Al & $42-\mathrm{Al}$ & $71-\mathrm{Al}$ & $42-\mathrm{Al}$ & 71-Al & 42-Al & $71-\mathrm{Al}$ & $42-\mathrm{Al}$ \\
\hline & \multicolumn{2}{|c|}{$\left(\mathrm{kg} \mathrm{ha}^{-1}\right)$} & \multicolumn{2}{|l|}{ (rating) } & \multicolumn{2}{|c|}{ (number) } & \multicolumn{2}{|l|}{ (days) } & \multicolumn{2}{|l|}{ (cm) } \\
\hline \multicolumn{11}{|l|}{ Hybrids } \\
\hline AS-T $\times$ AS-T $(18)^{a}$ & 3060 & 5330 & 1.02 & 1.0 & 27 & 31 & 67 & 65 & 210 & 244 \\
\hline AS-T $\times$ AS-S (20) & 2540 & 4840 & 1.77 & 1.0 & 22 & 30 & 72 & 70 & 148 & 200 \\
\hline$A S-S \times A S-S(2)$ & 110 & 3370 & 4.00 & 1.0 & 16 & 28 & 79 & 68 & 55 & 117 \\
\hline Mean & 2230 & 4510 & 2.26 & 1.0 & 22 & 30 & 73 & 68 & 138 & 187 \\
\hline \multicolumn{11}{|l|}{ Parents } \\
\hline AS-T Female (2) & 1820 & 2140 & 1.17 & 1.0 & 19 & 27 & 72 & 71 & 136 & 159 \\
\hline Male (9) & 3320 & 4770 & 1.33 & 1.0 & 23 & 32 & 77 & 76 & 140 & 168 \\
\hline AS-S Female (2) & 830 & 2170 & 3.00 & 1.0 & 17 & 29 & 79 & 74 & 62 & 98 \\
\hline Male (1) & 1040 & 110 & 4.00 & 1.0 & 17 & 33 & 82 & 63 & 105 & 109 \\
\hline Mean & 1750 & 2550 & 2.38 & 1.0 & 19 & 30 & 78 & 71 & 111 & 134 \\
\hline $\operatorname{LSD}(0.05)^{b}$ & 1270 & 1940 & 0.64 & NS $^{\mathrm{d}}$ & 6.8 & 9 & 4.8 & 5.8 & 22 & 15 \\
\hline
\end{tabular}

${ }^{a}$ Numbers in parentheses refer to number of genotypes used to calculate means.

${ }^{b}$ LSD values for differences among type of hybrids, among parents and between hybrids and parents.

c 1 = acid-soil tolerant, $4=$ acid-soil sensitive.

${ }^{\mathrm{d}} \mathrm{NS}=$ not significant. 
Table 4. Performance of $\mathrm{F}_{1}$ hybrids from acid-soil tolerant (AS-T) $\times$ AS-T, AS-T $\times$ acid-soil sensitive (AS-S), and AS-S $\times$ AS-S crosses, female and male parents grown at $67 \%(67-\mathrm{Al})$ and $43 \%(43-\mathrm{Al}) \mathrm{Al}$ saturation at Quilichao, Colombia during season $\mathrm{B}$

\begin{tabular}{|c|c|c|c|c|c|c|c|c|c|c|}
\hline \multirow{3}{*}{ Genotype } & \multicolumn{2}{|c|}{ Grain yield } & \multicolumn{2}{|c|}{ Acid-soil tolerance $^{c}$} & \multicolumn{2}{|c|}{ Number of roots } & \multicolumn{2}{|c|}{ Flowering } & \multicolumn{2}{|c|}{ Plant height } \\
\hline & $67-\mathrm{Al}$ & $43-\mathrm{Al}$ & $67-\mathrm{Al}$ & 43-Al & 67-Al & 43-Al & $67-\mathrm{Al}$ & 43-Al & 67-Al & 43-Al \\
\hline & \multicolumn{2}{|c|}{$\left(\mathrm{kg} \mathrm{ha}^{-1}\right)$} & \multicolumn{2}{|l|}{ (rating) } & \multicolumn{2}{|c|}{ (number) } & \multicolumn{2}{|l|}{ (days) } & \multicolumn{2}{|l|}{$(\mathrm{cm})$} \\
\hline \multicolumn{11}{|l|}{ Hybrids } \\
\hline As-T $\times$ AS-T (9) & 3300 & 4040 & 1.22 & 1.0 & 30 & 44 & 80 & 72 & 189 & 228 \\
\hline AS-T $\times$ AS-S (28) & 3680 & 3750 & 1.28 & 1.0 & 27 & 35 & 72 & 68 & 182 & 214 \\
\hline AS-S $\times$ AS-S (3) & 330 & 2930 & 3.72 & 1.0 & 19 & 34 & 78 & 64 & 82 & 134 \\
\hline \multirow[t]{2}{*}{ Mean } & 3340 & 3760 & 1.45 & 1.0 & 27 & 37 & 74 & 68 & 176 & 211 \\
\hline & & & & & & & & & & \\
\hline \multicolumn{11}{|l|}{ Parents } \\
\hline AS-T Female (1) & 2840 & 1430 & 1.0 & 1.0 & 23 & 39 & 75 & 69 & 95 & 122 \\
\hline Male (9) & 3150 & 3660 & 1.5 & 1.0 & 24 & 31 & 77 & 72 & 146 & 172 \\
\hline AS-S Female (3) & 230 & 1820 & 3.89 & 1.0 & 14 & 31 & 80 & 68 & 60 & 117 \\
\hline Male (1) & 20 & 2070 & 4.0 & 1.0 & 10 & 29 & 85 & 65 & 15 & 108 \\
\hline Mean & 2250 & 3030 & 2.13 & 1.0 & 21 & 31 & 78 & 70 & 114 & 152 \\
\hline $\operatorname{LSD}(0.05)^{b}$ & 510 & 660 & 0.60 & $\mathrm{NS}^{\mathrm{d}}$ & 7.5 & 12 & 3.2 & 1.7 & 17 & 30 \\
\hline
\end{tabular}

${ }^{a}$ Numbers in parentheses refer to number of genotypes used to calculate means.

${ }^{b}$ LSD values for differences among type of hybrids, among parents and between hybrids and parents.

$c 1=$ acid-soil tolerant, 4 = acid-soil sensitive.

${ }^{\mathrm{d}} \mathrm{NS}=$ not significant.

Table 5. Mean squares and coefficients of variation (c.v.) for grain yield, acid-soil tolerance, number of roots, flowering and plant height of sorghum hybrids and parents grown at $71 \%$ and $67 \% \mathrm{Al}$ saturation in seasons $\mathrm{A}(\mathrm{A})$ and $\mathrm{B}(\mathrm{B})$, respectively

\begin{tabular}{|c|c|c|c|c|c|c|c|c|c|c|c|}
\hline \multirow{2}{*}{$\begin{array}{l}\text { Source of } \\
\text { variation }\end{array}$} & \multirow{2}{*}{$\begin{array}{l}\text { Degrees of } \\
\text { freedom }\end{array}$} & \multicolumn{2}{|l|}{ Grain yield } & \multicolumn{2}{|c|}{ Acid-soil tolerance } & \multicolumn{2}{|c|}{ Number of roots } & \multicolumn{2}{|l|}{ Flowering } & \multicolumn{2}{|c|}{ Plant height } \\
\hline & & $\mathbf{A}$ & B & A & B & A & B & $\mathbf{A}$ & B & $\mathbf{A}$ & B \\
\hline Genotypes & 53 & $2,265,694^{* *}$ & $6,560,167^{* *}$ & $1.90^{* *}$ & $2.48^{* *}$ & $56.2^{* *}$ & $93.4^{* *}$ & $85.2^{* *}$ & $62.1^{* *}$ & $7042^{* *}$ & $8141^{* *}$ \\
\hline Hybrids (H) & 39 & $1,670,515^{* *}$ & $5,306,985^{* *}$ & $1.48^{* *}$ & $1.52^{* *}$ & $53.5^{* *}$ & $64.8^{* *}$ & $64.2^{* *}$ & $52.4^{* *}$ & $7071^{*}$ & $4997^{* *}$ \\
\hline Male (M) & 9 & $2,054,855^{* *}$ & $15,779,461^{* *}$ & $20.32^{* *}$ & $5.41^{*}$ & $33.0^{*}$ & $11.3^{* *}$ & $37.9^{* *}$ & $35.6^{* *}$ & $15573^{* *}$ & $20294^{* *}$ \\
\hline Female (F) & 3 & $8,449,520^{* *}$ & $1,358,783^{* *}$ & $47.05^{* *}$ & $0.46^{*}$ & $474.8^{* *}$ & $115.3^{* *}$ & $520.3^{* *}$ & $393.8^{* *}$ & $40974^{* *}$ & $1164^{* *}$ \\
\hline $\mathbf{M} \times \mathbf{F}$ & 27 & $789,178^{* *}$ & $2,254,849^{* *}$ & $1.55^{*}$ & $0.34^{*}$ & 13.6 & $43.6^{*}$ & $22.3^{* *}$ & $19.6^{* *}$ & $469^{* *}$ & $323^{* *}$ \\
\hline Parents vs $\mathbf{H}$ & 1 & 415,862 & $38,762,021^{* *}$ & $1.20^{*}$ & $14.6^{* *}$ & $144.8^{* *}$ & $969.1^{* *}$ & $1346.9^{* *}$ & $589.0^{* *}$ & $55513^{* *}$ & $124707^{* *}$ \\
\hline Error $A^{a}$ & 106 & 618,353 & 99,188 & 0.16 & 0.14 & 17.8 & 21.6 & 8.79 & 4.01 & 182 & 114 \\
\hline Error $\mathbf{B}^{\mathbf{a}}$ & 78 & 631,895 & 111,087 & 0.09 & 0.08 & 15.8 & 22.3 & 10.3 & 3.04 & 180 & 109 \\
\hline c.v. & & 29.4 & 10 & 25 & 19.5 & 18.4 & 17.8 & 4.1 & 2.4 & 8.4 & 5.9 \\
\hline
\end{tabular}

* ** Significant at the $P<0.05$ and $P<0.01$, respectively.

${ }^{a}$ Error $\mathbf{A}$ is residual mean square of analysis including parental lines; Error $\mathbf{B}$ is residual mean square of analysis of combining ability excluding parental lines. 
Table:6. Mean squares and coefficients of variation (c.v.) for grain yield, acid-soil tolerance, number of roots, flowering and plant height of sorghum hybrids and parents grown at $42 \%$ and $43 \%$ Al saturation in season A (A) and B (B), respectively

\begin{tabular}{|c|c|c|c|c|c|c|c|c|c|c|c|}
\hline \multirow{2}{*}{$\begin{array}{l}\text { Source of } \\
\text { variation }\end{array}$} & \multirow{2}{*}{$\begin{array}{l}\text { Degrees of } \\
\text { freedom }\end{array}$} & \multicolumn{2}{|l|}{ Grain yield } & \multicolumn{2}{|c|}{ Acid-soil tolerance } & \multicolumn{2}{|c|}{ Number of roots } & \multicolumn{2}{|c|}{ Flowering } & \multicolumn{2}{|c|}{ Plant height } \\
\hline & & $\bar{A}$ & B & $\bar{A}$ & B & A & B & $\mathbf{A}$ & B & A & B \\
\hline Genotypes & 53 & $5,802,921^{* *}$ & $2,988,632^{* *}$ & 0 & 0 & $59.8^{* *}$ & $176.5^{* *}$ & $77.6^{* *}$ & $314.0^{* *}$ & $8505^{* *}$ & $7575^{* *}$ \\
\hline Hybrids (H) & 39 & $37,009,088^{* *}$ & $2,133,950^{* *}$ & 0 & 0 & $56.5^{* *}$ & $175.0^{* *}$ & $47.5^{* *}$ & $28.6^{* *}$ & $6890^{\circ *}$ & $6001^{* *}$ \\
\hline Male (M) & 9 & $6,139,841^{* *}$ & $2,074,584^{* *}$ & 0 & 0 & $73.3^{*}$ & $244.1^{* *}$ & $26.0^{*}$ & $32.6^{* *}$ & $21051^{* *}$ & $22948^{* *}$ \\
\hline Female (F) & 3 & $16,665,648^{* *}$ & $1,676,187^{* *}$ & 0 & 0 & $144.9^{* *}$ & $665.6^{* *}$ & $323.2^{*}$ & $195.4^{* *}$ & $23740^{* *}$ & $4905^{*}$ \\
\hline$M \times F$ & 27 & $1,459,218$ & $2,204,601^{* *}$ & 0 & 0 & 41.1 & $90.8^{*}$ & $24.0^{* *}$ & $8.7^{*}$ & $297^{* *}$ & 474 \\
\hline Parents vs $\mathbf{H}$ & 1 & $47,461,472^{* *}$ & $16,520,211^{* *}$ & 0 & $\mathbf{0}$ & 16.4 & $1083.8^{*}$ & $1853.1^{*}$ & $125.5^{*}$ & $125081^{* *}$ & $108519^{* *}$ \\
\hline Error $A^{a}$ & 106 & $1, \mathbf{4 4 0 , 3 0 1}$ & 167,218 & $\mathbf{0}$ & 0 & 29.9 & 50.9 & 12.8 & 1.16 & 88.3 & 345 \\
\hline Error $B^{a}$ & 78 & $1,600,449$ & 198,965 & 0 & 0 & 25.6 & 48.4 & 14.4 & 1.09 & 76.4 & 361 \\
\hline c.v. & & 25.7 & 11.9 & 0 & 0 & 18.0 & 18.9 & 5.1 & 1.5 & 4.7 & 9.0 \\
\hline
\end{tabular}

*, ** Significant at the $\mathrm{P}<0.05$ and $\mathrm{P}<0.01$, respectively.

Error $\mathbf{A}$ is residual mean square of analysis including parental lines; Error B is residual mean square of analysis of combining ability excluding parental lines. 
Table 7. Grain yield, acid-soil tolerance, and number of roots of sorghum male and female parental lines and their $\mathrm{F}_{1}$ hybrids grown at $67 \%$ Al saturation on acid Ultisol

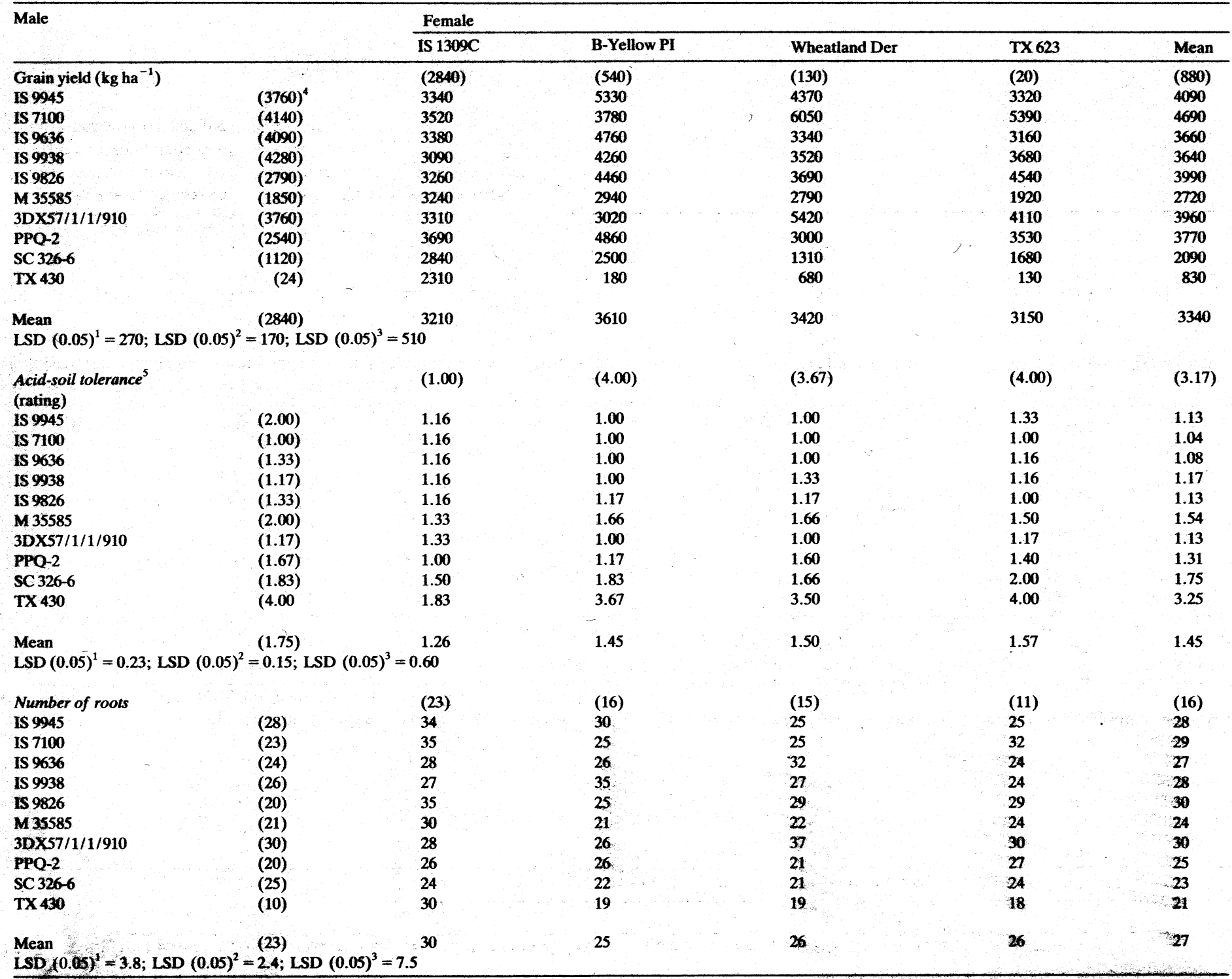

${ }^{1} \mathrm{~F}$ if differences among means of hybrids with common male parents.

${ }^{2}$ For tifftences among means of hybrids with common female parents.

3 For differences among hybrids and parents.

4 Numbers in parentheses are parental values.

$5_{1}=$ acid soil theynt. $2=$ acid soil sensitive. 
Table 8. Flowering and plant height of sorghum male and female parental lines and their $\mathrm{F}_{1}$ hybrids grown at $67 \%$ Al saturation on acid Ultisol

\begin{tabular}{|c|c|c|c|c|c|c|}
\hline \multirow[t]{2}{*}{ Male } & & \multicolumn{3}{|l|}{ Female } & \multicolumn{2}{|c|}{. } \\
\hline & & IS 1309C & B-Yellow PI & Wheatland Der & TX 623 & Mean \\
\hline Flowering (days) & & (75) & (79) & (85) & (76) & (79) \\
\hline IS 9945 & $(78)^{4}$ & 81 & 71 & 73 & 74 & 75 \\
\hline IS 7100 & (72) & 80 & 71 & 71 & 70 & 73 \\
\hline IS 9636 & (79) & 81 & 72 & 74 & 73 & 75 \\
\hline IS 9938 & (76) & 82 & 71 & 73 & 73 & 75 \\
\hline IS 9826 & (77) & 78 & 71 & 72 & 73 & 73 \\
\hline M 35585 & (82) & 74 & 69 & 68 & 75 & 71 \\
\hline $3 D \times 57 / 1 / 1 / 910$ & (76) & 81 & 69 & 70 & 72 & 73 \\
\hline PPQ-2 & (74) & 78 & 70 & 71 & 72 & 73 \\
\hline SC $326-6$ & (84) & 83 & 71 & 71 & 78 & 76 \\
\hline TX 430 & (85) & 75 & 79 & 74 & 80 & 77 \\
\hline Mean & (78) & 79 & 71 & 72 & 74 & 74 \\
\hline \multicolumn{7}{|c|}{$\operatorname{LSD}(0.05)^{1}=1.4 ; \operatorname{LSD}(0.05)^{2}=0.9 ; \operatorname{LSD}(0.05)^{3}=3.2$} \\
\hline Plant height $(\mathrm{cm})$ & & (95) & (83) & $(58)$ & (39) & (69) \\
\hline IS 9945 & (166) & 207 & 212 & 196 & 214 & 207 \\
\hline IS 7100 & (173) & 211 & 197 & 212 & 205 & 206 \\
\hline IS 9636 & (159) & 211 & 203 & 201 & 213 & 207 \\
\hline IS 9938 & (209) & 195 & 197 & 197 & 204 & 198 \\
\hline IS 9826 & (131) & 207 & 189 & 195 & 210 & 200 \\
\hline M 35585 & (133) & 191 & 171 & 165 & 172 & 175 \\
\hline 3DX57/1/1/910 & (141) & 190 & 186 & 197 & 211 & 196 \\
\hline PPQ-2 & (119) & 169 & 169 & 150 & 172 & 165 \\
\hline SC 326-6 & $(82)$ & 119 & 112 & 100 & 115 & 111 \\
\hline TX 430 & (15) & 133 & 86 & 85 & 75 & 95 \\
\hline $\begin{array}{l}\text { Mean } \\
\operatorname{LSD}(0.05)^{1}=9\end{array}$ & $\begin{array}{l}(133) \\
5 ; \text { LSD }\end{array}$ & 183 & 172 & 170 & 179 & 176 \\
\hline
\end{tabular}

${ }^{1}$ For differences among means of hybrids with common male parents.

${ }^{2}$ For differences among means of hybrids with common female parents.

${ }^{3}$ For differences among hybrids and parents.

${ }^{4}$ Numbers in parentheses are parental values. 
Table 9. Grain yield, acid-soil tolerance, and number of roots of sorghum male and female parental lines and their $\mathrm{F}_{1}$ hybrids grown at $43 \% \mathrm{Al}$ saturation on acid Ultisol

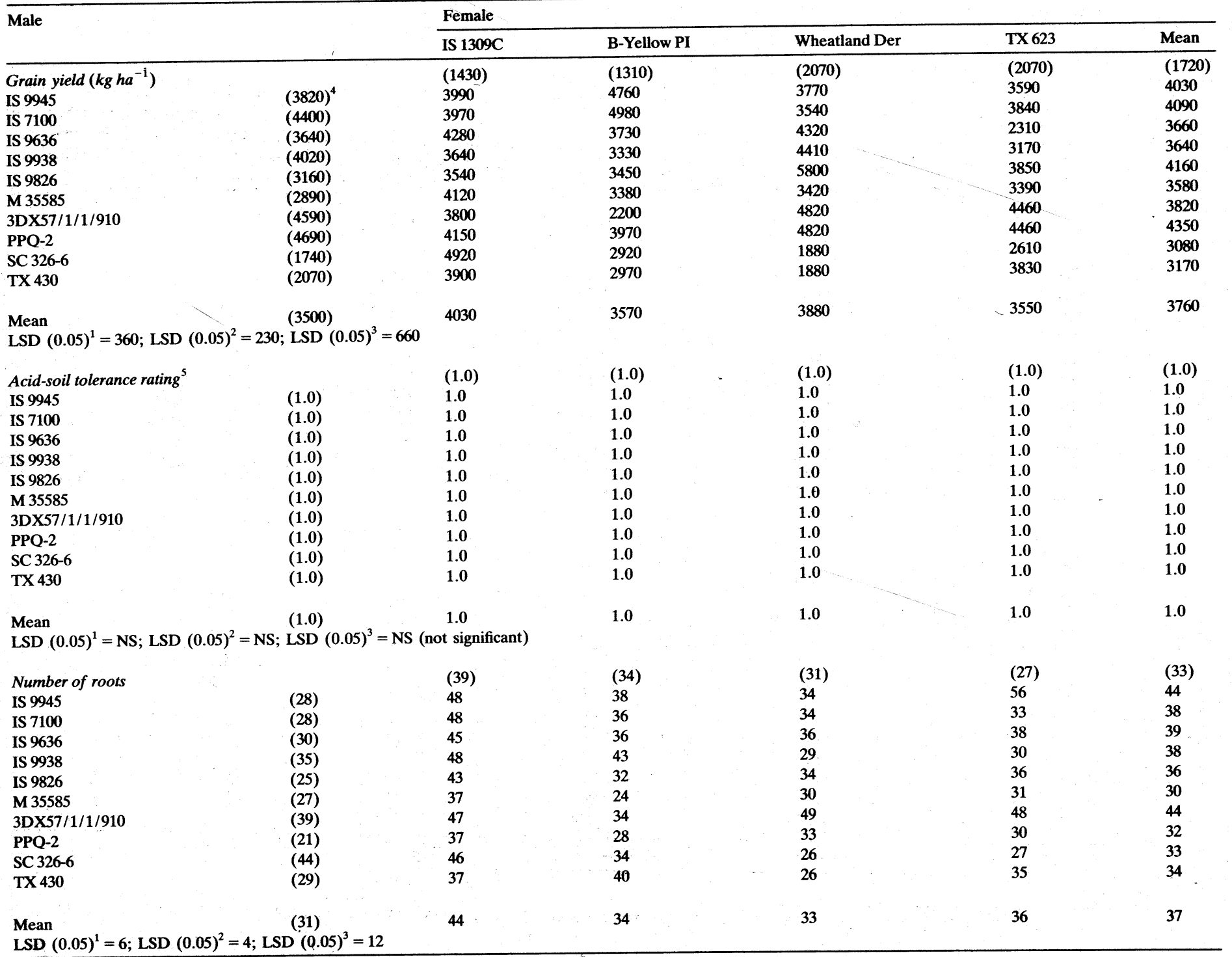

${ }^{1}$ For differences among means of hybrids with common male parents.

${ }^{2}$ For differences among means of hybrids with common female parents.

${ }^{3}$ For differences among hybrids and parents.

${ }_{5}^{4}$ Numbers in parentheses are parental values.

${ }^{5} 1$ = acid-sourtoletrantc 4 = acid-soil sensitive. 
Table 10. Flowering and plant height of sorghum male and female parental lines and their $\mathrm{F}_{1}$ hybrids grown at $43 \%$ Al saturation on acid Ultisol

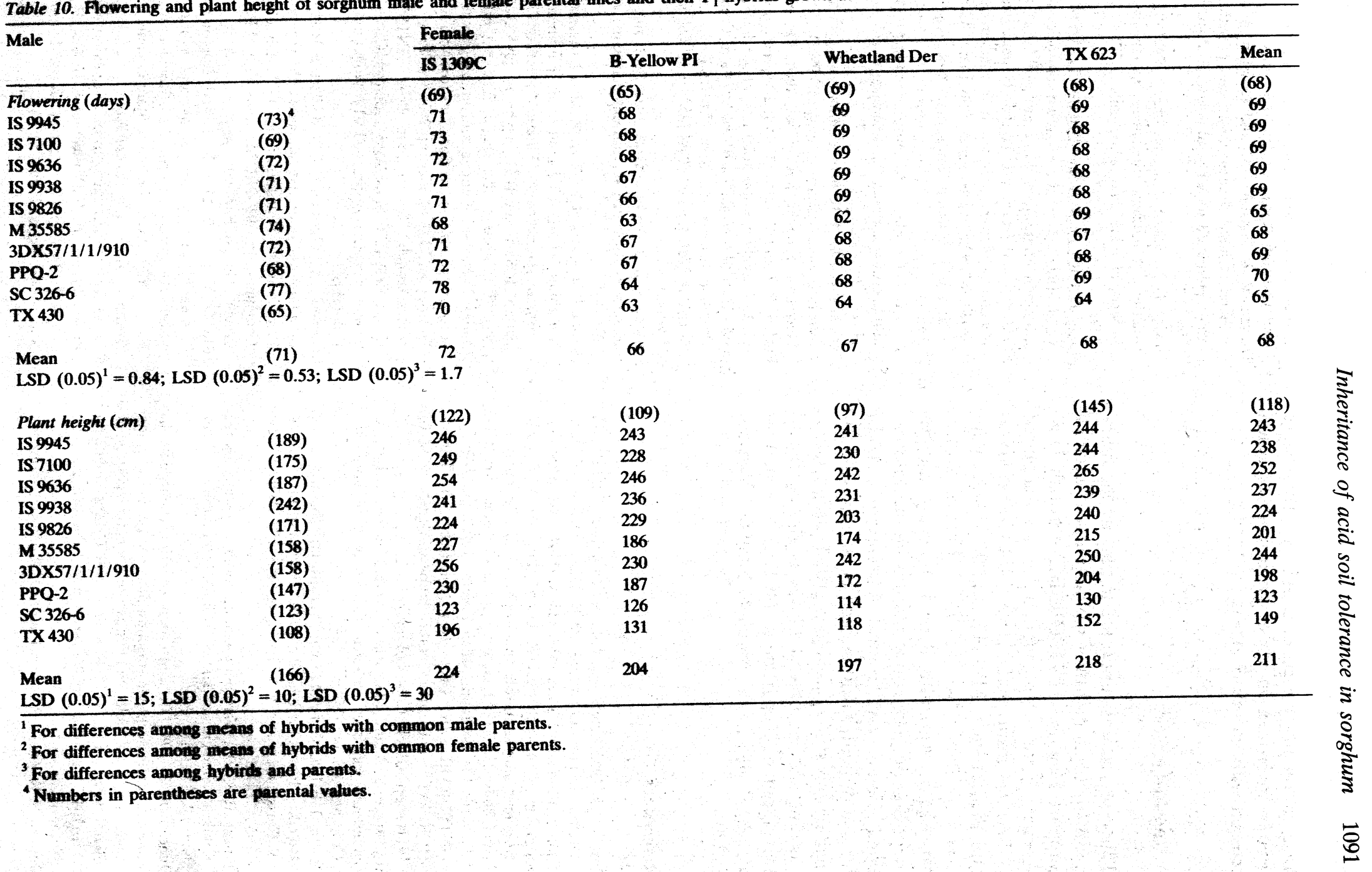


ance, and number of roots of AS-S parents were greatly improved in these environments when crossed with an AS-T parent.

\section{Acknowledgements}

This research was supported in part by the International sorghum/Millet Collaborative Research Support Program (INTSORMIL) through U.S. Agency for International Development (USAID) grant AID/DAN-1254-G-SS-5065-00 and Project Nos. MS-111 and NE-114A. Published as Paper No. PS-7513, Journal Series, Mississippi Agricultural and Forestry Experiment Station. The cooperation from the International Center for Tropical Agriculture (CIAT) for use of land, facilities, and personnel, and for making this study possible is greatly appreciated. Current address of C I Flores is Research and Development Department, CERES International, A P 484, Los Mochis, Sinaloa, Mexico, 81220 .

\section{References}

Bastos C R 1982 Inheritance study of aluminum tolerance in sorghum in nutrient culture. Ph.D. Diss., Mississippi State Univ., Mississippi State, MS. (Diss. Abstr. 40, 2069-B).

Borgonovi R A, Schaffert R E and Pitta G V E 1987 Breeding aluminum-tolerant sorghums. In Sorghum for Acid Soils. Eds. L M Gourley and J G Salinas. pp 271292. Proc Int. Sorghum/Millet Collab. Res. Support Prog. (INTSORMIL), Int. Crops Res. Inst. Semi-Arid Tropics (ICRISAT), and Int. Center Tropical Agric. (CIAT) Workshop. CIAT, Cali, Colombia.

Boye-Goni S R and Marcarian V 1985 Diallel analysis of aluminum tolerance in selected lines of grain sorghum. Crop Sci. 25, 749-752.

Devine T E 1982 Genetic fitting of crops to problem soils. In Breeding Plants for Less Favorable Environments. Eds. M N Christiansen and C F Lesis. pp 143-173. Wiley, New York.

Duncan R R 1981 Variability among sorghum genotypes for uptake of elements under acid soil field conditions. J. Plant Nutr. 4, 21-32.

Duncan R R 1983 Concentration of critical nutrients in tolerant and susceptible sorghum lines for use in screening under acid soil field conditions. In Genetic Aspects of Plant Nutrition. Eds. M R Saric and B C Loughman. pp 101-104. Martinus Nijhoff Publishers, The Hague, The Netherlands.

Duncan R R, Clark R B and Furlani P R 1983a Laboratory and field evaluations of sorghum for response to aluminum and acid soil. Agron. J. 75, 1023-1026.

Duncan R R, Sutton J D and Dominy R E 1983b Leaf mineral element concentrations and growth of sweet sorghum subjected to acid soil stress. J. Plant Nutr. 6, 781799.

Duvick D N, Kluse R A and Frey N M 1981 Breeding for tolerance to nutrient imbalances and constraints to growth in acid, alkaline, and saline soils. J. Plant Nutr. 4, 111129.

Flores C I, Clark R B and Gourley L M 1988 Growth and yield traits of sorghum grown on acid soil at varied aluminum saturations. Plant and Soil 106, 49-57.

Flores C I and Gourley L M 1987 Genetic variation in two aluminum-tolerant grain sorghum random-mating populations. In Abstr. tech. papers, Southern Assn. Agric. Scientists. p. 3. Southern Branch Am. Soc. Agron., Nashville, TN.

Flores C I, Gourley L M and Coronado M 1986 Screening and breeding sorhgum for tolerance to acid soils. Sorghum Newsl. 29, 3-4.

Furlani P R 1981 Effects of aluminum on growth and mineral nutrition of sorghum genotypes. Ph.D. Diss. Univ. of Nebraska, Lincoln, NE. (Diss. Abstr. 42, 1260-B).

Furlani P R and Bastos C R 1986 Evidence of simple genetic control involved in the tolerance of sorghum to aluminum. In Abstr. 16th Brazilian Corn Sorghum Congr. pp 86-87. Brazilian Inst. Agric. Res. (EMBRAPA) and Nat. Corn Sorghum Res. Center (CNPMS), Sete Lagoas, Brazil. (In Portuguese).

Furlani P R and Clark R B 1981 Screening sorghum for aluminum tolerance in nutrient solutions. Agron. J. 73, 587-594.

Furlani P R, Clark R B, Ross W M and Maranville J W 1983 Variability and genetic control of aluminum tolerance in sorghum genotypes. In Genetic Aspects of Plant Nutrition. Eds. M R Saric and B C Loughman. pp 453-461. Martinus Nijhoff Publishers, The Hague, The Netherlands.

Gourley L M 1987 Finding and utilizing exotic Al-tolerant sorghum gemplasm. In Sorghum for Acid Soil. Eds. L M Gourley and J G Salinas. pp 293-309. Proc. Int. Sorghum/ Millet Collab. Res. Support Prog. (INTSORMIL), Int. Crops Res. Inst. Semi-Arid Tropics (ICRISAT), and Int. Center Tropical Agric. (CIAT) Workshop. CIAT, Cali, Colombia.

Magnavaca R, Gardner C O and Clark R B 1987 Inheritance of aluminum tolerance in maize. In Genetic Aspects of Plant Mineral Nutrition. Eds. W H Gabelman and B C Loughman. pp 201-212. Martinus Nijhoff Publishers, Dordrecht, The Netherlands.

Pitta G V E, Schaffert R E and Borgonovi R A 1979 Evaluation of sorghum parents and hybrids to high soil acidity conditions. In Proc. 12th Brazilian Maize Sorghum Rev. p. 127. Agric Res. Inst. State Goiania (EMBRAPA), Goiania, Brazil. (In Portuguese).

Reid D A 1969 Genetic control of reaction to aluminum in winter barley. In Barley Genetics II. Ed. R A Nilan. pp 409-413. Proc. 2nd Int. Barley Genet. Symp. Washington State Univ. Press, Pullman, WA. 
Rhue R D 1979 Differential aluminum tolerance in crop plants. In Stress Physiology in Crop Plants. Eds. H Mussell and R C Staples. pp 61-80. Wiley, New York.

Ross W M, Gorz H J, Haskins F A, Hookstra G H, Rutto J K and Ritter R 1983 Combining ability effects for forage residue traits in grain sorghum hybrids. Crop Sci. 23, 97-101.

Sanchez P A and Salinas J G 1981 Low-input technology for managing oxisols and ultisols in tropical America. Adv. Agron. 34, 279-405. 